\title{
ARTYKUŁY
}

Klio. Czasopismo poświęcone dziejom Polski i powszechnym

PL ISSN 1643-8191, t. 43 (4)/2017, s. 23-45

(c) $(1) \Theta$

http://dx.doi.org/10.12775/KLIO.2017.043

Michalina Duda, SŁaWOMir JóŹWiak"

\section{Nowa Nieszawa (Dybów) in the late Middle Ages according to new research. The town on the border of countries, cultures and nations"}

\section{Nowa Nieszawa (Dybów) w późnym średniowieczu. Miasto na pograniczu państw, kultur i narodów}

Streszczenie: Nowa Nieszawa, lokowana nad Wisłą na pograniczu polsko-krzyżackim po 1423 roku, jawi się jako prężnie rozwijający się pod względem gospodarczym i politycznym ośrodek miejski. Dzięki swojej lokalizacji na trasie niezwykle istotnego szlaku handlowego, a także w najbliższym sąsiedztwie państwa krzyżackiego przyciągała przedsiębiorcze jednostki, przede wszystkim kupców i rzemieślników różnej narodowości, a także zbiegów

M. Duda: broda.michalina@gmail.pl; S. Jóźwiak: sj@umk.pl; Instytut Historii i Archiwistyki UMK w Toruniu, ul. W. Bojarskiego 1, 87-100 Toruń.

${ }^{* *}$ M. Duda's research was financed by the National Science Center, Poland granted according to decision no. DEC-2012/05/N/HS3/01398 as well as the Foundation for Polish Science (FNP); S. Jóźwiak's contribution to this paper is a part of the project no. 2012/05/B/HS3/03708 financed by the National Science Centre, Poland. 
z pobliskiego państwa krzyżackiego. Funkcjonowanie Nowej Nieszawy jest tym bardziej godne zainteresowania, że pozycja tego ośrodka ukształtowała się w dość ograniczonych ramach czasowych: jego lokację od zrównania z ziemią dzielił odstęp nieco mniej niż czterech dekad. Należy jednak podkreślić, że swój fenomen Nieszawa zawdzięczała przede wszystkim niezwykle korzystnej lokalizacji na pograniczu dwóch państw.

Abstract: Nowa Nieszawa, chartered on the Vistula river on the Polish and Teutonic border after 1423 , seems to have been a rapidly growing town in economic and political terms. Its location along an extremely important trade route as well as in the direct vicinity of the State of the Teutonic Order, caused that Nowa Nieszawa attracted enterprising individuals mostly merchants and craftsmen of various ethnic backgrounds as well as fugitives from the nearby Teutonic Order's State. The functioning of Nowa Nieszawa is all the more worthy of attention as the position and importance of this town was formed in quite a constrained timeframe: the time span between granting the town with the charter and razing it to the ground took a little less than four decades. There is no doubt, that Nieszawa's phenomenon is a result of favourable location the city on the border between the two countries.

Słowa kluczowe: Nowa Nieszawa; XV wiek; pogranicze; Królestwo Polskie Keywords: Nowa Nieszawa; 15th century; border; Kingdom of Poland

7 he establishment of the southern border between the Kingdom of middle of the Vistula river's course (it was one of the conditions of the peace treaty signed on 27 September 1422 at Lake Mełno) was of great importance for the increasing political significance and economic development of the former territories belonging to the Teutonic Order in Cuiavia. At the order of King Władysław II Jagiełło of Poland a village called Nieszawa (or Nowa Nieszawa) was immediately founded on the bank of the Vistula, just opposite Thron (Toruń). Early on next year (1424) at the latest, this village was granted rights by the monarch. This new centre in the contemporary historical sources was most frequently described as "Noua Nieschowa." Nevertheless, it is difficult to explain the reason why in Teutonic sources, at least since 1425 , this newly founded town was more frequently referred to as "Dybaw" ("Dybow") and, further, what the origin of this name could be. Nowa Nieszawa was developing rapidly owing to its favourable location 
on the Vistula River at the border river crossing and along an extremely important trade route - from Cuiavia via the Teutonic Order's State and then to the Baltic Sea - that used both land and water routes (i.e. the Vistula). A local council-type government, including the mayor, the council and the councillors, was operating in Nowa Nieszawa since the town was granted its rights. Important buildings that performed either representative or ecclesiastical functions (churches, a townhall) were made of brick, yet wooden or timber-framed architecture was also present. At least until the end of 1430s., Nowa Nieszawa had no fortifications, and those that were erected in the later periods were merely wood and earthen fortifications. In the areas surrounding the town and eastwards, King Władysław II Jagiełło had a brick castle built in 1427-1430; this castle became the seat of Polish burgraves on behalf of the starosts of Inowroctaw in the second half of the $15^{\text {th }}$ century ${ }^{1}$.

\section{The economic role of the town}

Even the first historical mentions in medieval written sources stress a rapid economic development of the newly chartered town. The document issued by King Władysław II Jagiełło on 29 May 1425 says that Marcin of Gaworzyna, canon of Gniezno and the monarch's secretary, together with his brother, identified only with sigillum "N", obtained a plot of land in Nieszawa to build a house and a granary. The plot was located close to another one that was the property of Deputy Chancellor of the Crown and custos in Gniezno, Stanisław Ciołek, and it could be found next to the Church of the Great Commission. Marcin of Gaworzyna and his brother

1 The very beginnings and the system of Nowa Nieszawa as well as the castle in the town's vicinity are extensively analysed in cf. S. Jóźwiak, Nowa Nieszawa (Dybów) naprzeciw Torunia w latach 1423-1460/62 w świetle średniowiecznych źródet pisanych, [in:] W poszukiwaniu zaginionego miasta: 15 lat badań średniowiecznej lokalizacji Nieszawy, eds. A. Andrzejewski and P. Wroniecki, Łódź 2015, p. 13-34; S. Jóźwiak, J. Trupinda, Zamek w Nowej Nieszawie (Dybowie) w świetle średniowiecznych źródet pisanych, Rocznik Toruński 42 (2015), p. 171-184. 
could thus store grain in the granary they built, in this manner exercising the rights other residents of the town were entitled to ${ }^{2}$.

First complaints on the other side of the border as to competitive commercial activity of Nieszawa appeared in sources very early, i.e., at the convention of Prussian towns which was held on 17 February 1426 in Elbing (Elblag). They concerned three Danzig's (Gdańsk) burghers (Hans Winterfeldt, Lambert Reichen and Michael Leeman) who, despite bans in force in the Teutonic Order's State, set up either a commercial company jointly with the residents of Nieszawa, or imported herrings to the town. These complaints also referred to some unnamed merchants from Culm (Chełmno) who illegally shipped some unspecified goods to Nieszawa ${ }^{3}$. At another convention of Prussian towns in Marienburg (Malbork), held on 21 April 1426, representatives of Thorn (they were particularly vigilant as to business relations with Nieszawa as it was a neighbouring town in Cuiavia) complained that some Danzig's residents entered into commercial partnerships with residents of Nieszawa, sailed by their vessels here (and the locals could hire those vessels), were buying, loading and unloading goods, and selling herrings, etc. Merchants from Thorn reminded that this was against bans that were valid in Prussia, and demanded from the local authorities in Danzig that persons responsible for the wrongdoing should bear consequences ${ }^{4}$. The same complaints were repeated at subsequent meetings, and those who prevailed in evading far-reaching restrictions on maintaining business contacts (introduced in the Teutonic Order's State) with Nieszawa residents were the residents of Danzig who saw opportunities to do good business in this new town in Cuiavia. It is not surprising that during the next convention of the estates (on 18 August 1426) new complaints were added to the already existing ones that mostly referred again to Danzig residents. These new complaints centred on buying grain in Nieszawa 5 .

2 Codex epistolaris Vitoldi Magni Ducis Lithuaniae 1376-1430, ed. A. Prochaska, P. 1-2, Cracoviae 1882 (Monumenta Medii Aevi Historica Res Gestas Poloniae Illustrantia, Vol. 6) (further as CEV), No. 1201, p. 702, Ref. 1.

${ }^{3}$ Acten der Ständetage Preussens unter der Herrschaft des Deutschen Ordens, hrsg. v. M. Toeppen, Leipzig 1878-1886 (further as Acten), Bd. I, No. 350.

${ }^{4}$ Ibidem, Bd. I, No. 352.

${ }^{5}$ Ibidem, Bd. I, No. 355. 
Very soon other grounds of conflicts emerged that were of business and commercial background. It soon turned out that both Danzig-based and foreign merchants ${ }^{6}$ (based in other countries) easily obtained the citizenship of Nowa Nieszawa, and they eagerly used this opportunity by carefully avoiding trade regulations that were in force in Prussia. It allowed them to purchase goods and grain in this Cuiavian town without any agency or without the need to respect the storage right, as well as to build houses, warehouses and granaries. It is not surprising that during the convention of estates in Marienburg (7 May 1427) representatives of Danzig received an order to apprehend - for the need of providing relevant explanations an alleged resident of Danzig, Mikołaj Struben, who was also a citizen of Nowa Nieszawa and used to sail by ship to this town (undoubtedly for commercial purposes) ${ }^{7}$.

While discussing the importance of Nowa Nieszawa in the supraregional trade (along the Vistula and maritime trade) one cannot forget that the town also used to play a vital role in the border areas of Cuiavia and the Culmerland. It was established along one of crucial land trade routes at the crossing of the river Vistula in Thorn. Interesting information about the town can be found in the letter, dated 11 May 1427, of the commander in Thorn to the Grand Master. The commander informed the Master that the Poles (the starost of Nieszawa) interfered with the merchants in their trade activity as the merchants were forced to use the road to Dybów (Nowa Nieszawa) and had to pay for the crossing - unfortunately, the author of the letter does not indicate whether as a fee for carriage, or as trade duties - in the amount of not just one grosch for the wagon, as it had already been established during the congress in which King Władysław II Jagiełło participated, but 8,10 , or even 12 grosch. For this reason, the merchants based in the Teutonic Order's State tried to search for and find other places where they could cross the Vistula and spend less on the fees charged. This

6 See further.

7 Hanserecesse. Die Recesse und andere Akten der Hansetage von 1256-1430, hrsg. v. K. Koppmann [et al.], Bd. VIII, Leipzig 1897 (further as Hanserecesse), Bd. VIII, No. 190, p. 140. 
situation, in the commander's view, resulted in decreasing importance of the crossing just opposite Thorn, and reduced crossing-related income ${ }^{8}$.

The representatives of the Teutonic Order brought about also the issue of Nieszawa in their two official letters, drafted in November 1431 and October 1432, which presented their political and military plans and activities to the Roman Curia and the Danish king. The Teutonic military attack on the town (at the end of August or in early September 1431) was to have been caused by the fact that Nieszawa was granted - by the Polish king - the right of storage covering all types of goods; these privileges were to have an impact on the Order, but most of all on Thorn-based merchants. Nowa Nieszawa was also a place where - protected by Polish officials - fugitives, or "villains" from Prussia were to stay and live9. On the other hand, in a complaint submitted in February 1432 at the Roman Curia, Teutonic envoys stressed that by having a town built in Nowa Nieszawa the Polish king violated the terms of the peace treaty of Lake Mełno (Article 23, specifically), because on the Cuiavian bank of the river Vistula there was enough place only for an inn and a toll point. Meanwhile, the monarch ordered to build a town at this place (not to mention a castle) and the merchants from the Teutonic Order's State were forced to store their goods there (under the right of storage?) ${ }^{10}$. By way of explanation it should be mentioned that article 23 of the Treaty of Lake Mełno does not provide for any restrictions that were mentioned by the Teutonic Order's representative at the Roman Curia in 1432.

${ }^{8}$ Secret State Archives Prussian Cultural Heritage Foundation (Geheimes Staatsarchiv Preußischer Kulturbesitz), Berlin-Dahlem, XX. Hauptabteilung, Ordensbriefarchiv (further as GStAPK, OBA), No. 4221.

9 Codex Epistolaris Saeculi Decimi Quinti, coll. A. Lewicki, Vol. 2, Cracoviae 1891 (Monumenta Medii Aevi Historica Res Gestas Poloniae Illustrantia, Vol. 12), Vol. 2, No. 200, No. 208.

$10,(.$.$) et contra articulum pacis 23$, in quo articulo cavetur, quod ex opposito predicti fluminis debuit et consuevit esse taberna, in qua alternatis vicibus debeat eligi collector navigii, et quod deterius est, in eodem novo opido mercatores ordinis mercimonias suas deponere (...) conpulit" - Die Berichte der Generalprokuratoren des Deutschen Ordens an der Kurie, bearb. v. H. Koeppen, Bd. IV, Halbband 1, Göttingen 1973 (further as Berichte), No. 346, p. 388. 
At the end of the next war between Poland and the Teutonic Order's State (lasting between 1431 and 1435) the residents of Thorn, anticipating the necessity to return the Cuiavian bank of the Vistula that had been occupied for several years to the opposite party, called for religious authorities to ensure the future protection of their interests. The document reporting on the convention held on 23 October 1435 in Thorn included a request that in the case of giving the land on the other side of the Vistula to the Poles, the latter were to declare not to rebuild Nowa Nieszawa (mostly houses and facilities that had been erected before and later on destroyed during the war) so that trade would not be ever possible in this town. The consent could be merely given to building an inn and a guesthouse for travellers ${ }^{11}$.

These demands came to no effect. As soon as the Poles, under the provisions of the Treaty of Brześć [Kujawski] (31 December 1435), recovered the Cuiavian bank of the Vistula river in the second half of $1436^{12}$, they immediately began rebuilding the destroyed town. Thus, after a few years complaints were again heard from various towns in the Teutonic Order's State (mainly from Thorn) on economic and trade competition posed by Nowa Nieszawa. At the convention held on 25 July 1441 in Marienwerder (Kwidzyn), the issues discussed were similar to those that had been constantly present in the earlier period of the town's existence (prior to September 1431), i.e., breaching the ban on ships docking in Nieszawa, purchasing grain here by merchants from the Teutonic Order's State (or importing it from Mazovia), or selling fish. Accusations were formulated against one of the officials of the Teutonic Order - manager of mills ("molemeyster") in Danzig for breaching the bans and sending people to Nieszawa to buy grain for his purposes ${ }^{13}$.

11 „Czum ersten umb das gebiete zu Nessaw, ab das wurde obirgeben, das do keyne stad noch gebewde, speicher noch dergleich ader nederlage gemacht, noch keyne kouffmanschacz czu ewigen czeiten do gehalden wurde, sunder alleyne eynen kretczem czu nutcze und herberge den wegefertigen und wander[n]den luten czu bauwen" - Acten, Bd. I, No. 544, p. 700-701.

${ }^{12}$ On chronology of regaining the Cuiavian bank of the Vistula, cf. S. Jóźwiak, Nowa Nieszawa, p. 43.

${ }^{13}$ Acten, Bd. II, No. 241, p. 357-358. 
During the convention of estates held in the Teutonic Order's State in the 1440s., the nature of most frequent complaints (usually formulated by Thorn residents) against Nieszawa and the locals was extended. The range of goods that were the subject of the incriminated trade was enhanced. Thus, at the convention in Elbing, held on 8 June 1444, a complaint addressing two persons from Danzig was lodged; these persons, violating bans, shipped oil and herrings to Nieszawa "on an alien ship", and took oats in return ${ }^{14}$. Unfair competition was something that burghers of New Town of Thorn complained about to the Thorn commander, and this fact is commonly known owing to his letter of 1 December 1444. Among other things, the residents of Nieszawa brewed and sold cheaper beer in Thorn, while Polish officials forbade the subjects of the Teutonic Order's State in Cuiavia to do the same. They also did not allow to export salt, mined in Poland, to the Teutonic Order's State ${ }^{15}$. As a result of all these complaints, by the order of the Grand Master of 1448, the subjects of the Teutonic Order's State could not sell, also to Nieszawa, old or new vessels, call at the local port on the Vistula and enter into any commodity-trading partnerships with local burghers ${ }^{16}$. Markets became a new element of mutual business competition at this time. A lot of information can be found in reports of the proceedings of the convention of estates held on 1 January 1449 in Marienburg. Thorn residents complained that the grain and food market (purchase and sale), once active in their town, was moved to Nieszawa, primarily because the Poles forced merchants to participate in local fairs. This resulted in the situation that even burghers from Thorn started to purchase goods there. They tried to counter this by setting up the fair on Thursday in the Old Town, and on Saturday in New Town of Thorn. Nieszawa responded with the same solutions. Therefore merchants, subjects of the Teutonic Order's State, demanded that the Grand Master should issue a ban for inhabitants of Prussia on calling at the local port and buying anything there, and he agreed to consider this demand ${ }^{17}$.

\footnotetext{
14 Acten, Bd. II, No. 369, p. 601.

15 Acten, Bd. II, No. 395, p. 632.

${ }^{16}$ Acten, Bd. III, No. 21, p. 50-51.

${ }^{17}$ Acten, Bd. III, No. 51, p. 90, 92.
} 
There is also no doubt that Nieszawa-based burghers were going for commodities on their own vessels and transported those commodities to Danzig and back. In October 1440, Zygmunt, burgrave of Nieszawa, asked the Danzig town councillors for the return of the ship that had been taken from Jan Plebanek (Plebanecker), a citizen of Nieszawa ${ }^{18}$. The Danzig city council in the letter dated 21 April 1441 explained to Polish officials (the starost of Brześć and burgrave of Nieszawa) that Jan Plebanek used to own the ship which even before the war (i.e., before 1431) sank in the Motława river (Danzig sources say that Plebanek sank the ship himself during military actions). However, in 1439 this ship was refloated and repaired by a townsman of the Old Town of Danzig, a man named Hildebrant, who was still using it as he was not refunded the costs borne. If he got them, he would be willing to return the ship ${ }^{19}$. Mikołaj Szarlejski of Ścibórz, starost of Inowrocław and Bydgoszcz had completely different information as to this matter. In his letter dated 14 October 1441 he demanded that the city council of Danzig returned the vessel (a punt) to Jan Plebanek, a burgher from Nieszawa. This ship was to have been taken from Plebanek during the peace negotiations (probably in late 1435) ${ }^{20}$. Relatively numerous complaints as to takeovers of ships and grain from residents of Nieszawa, made at an unspecified time by the Teutonic officials [the Schwetz (Świecie) commander, Vogt of Dirschau (Tczew)] and residents of Thorn, were attached to the letter sent on 29 August 1452 by the Thorn castle commander to Grand Master Ludwig von Erlichshausen ${ }^{21}$. Similar issues were discussed in the letter sent on 28 January 1454 from Kraków by Polish King Kazi-

${ }^{18}$ The State Archives in Gdańsk (Archiwum Państwowe w Gdańsku) (further as APG), Listy i dokumenty, 300, D/7, No. 19.

${ }^{19}$ APG, Letters and documents, 300, D/6, No. 24; 300, D/6, No. 70; 300, D/7, No. 20.

${ }^{20}$ APG, Letters and documents, 300, D/6, No. 26. This case took a long time. Even in the list of complaints of Nieszawa residents about the Teutonic Order's authorities and subjects, attached to the letter of the Thorn castle commander to the Grand Master, dated 29 August 1452, there was a complaint lodged by Jan Plebanek and addressed to the local authorities of the Old City of Danzig on seizing his boat „when Cuiavia was ravaged” (thus before 1436) - GStAPK, OBA, No. 11381.

${ }^{21}$ GStAPK, OBA, No. 11381. 
mierz Jagiellon to the Grand Master. A group of burghers from Nieszawa were received by the king, and informed him that in autumn of the previous year (i.e., 1453) they went on their vessels loaded with grain and other commodities via the Vistula to Danzig. On the way, however, they were negatively surprised by the winter, and the river was frozen, thus their ships were immobilised close to forested areas near the commander castle in Mewe (Gniew). Commodities and corn did freeze, yet the Nieszawa residents were more concerned with something else. On their behalf the king addressed the Grand Master so that the latter committed the Mewe commander to protect these ships and loads against looting as this would yield huge losses to Nieszawa residents ${ }^{22}$. It is worth noting that the persons concerned presented their problem to the king (in Kraków?). Was it possible that they left their ice-immobilised ships with goods near Mewe (with people on guard?) and go by land alone, and in winter, to Kraków to see the monarch? This can be one of the ways the information included in the letter might be interpreted. The above references seem to imply that Nieszawa-based merchants tried to trade directly with Danzig, and this did give rise to conflicts with the residents of the Teutonic Order's State.

\section{Residents}

With a view to analysing the social community of Nowa Nieszawa in historical sources, what may be of particular research interest is the fact that, apart from many Poles (who mainly came from Cuiavia), it was a town in which representatives of many regions and nations used to live; this claim can be supported by direct major evidence.

In a letter drafted on 10 May 1427, starost of Inowrocław and Nieszawa Mikołaj Tumigrała asked Grand Master Paul von Rusdorf to grant a certain burgher from Nowa Nieszawa, named Wiktor (who was travelling with this letter to the Grand Master), a safe conduct for safe stay in Prussia and the possibility of a legal settlement of the dispute that he had with some

${ }^{22}$ GStAPK, OBA, No. 12755. 
merchants ("whether they would be the Dutch or Brabanters or others") 23. The core issue of the dispute is not known, but in light of the information given by this source one may consider the origin of abovementioned Wiktor. In another letter, this time of 17 March 1428, the same Polish starost asked the Grand Master for providing assistance - in recovering money - to a burgher from Nowa Nieszawa named Wincenty ("Vinczentius"). Some Teutonic subjects from Prussia owed him this money. For this reason, the starost sent him with the letter to the Grand Master ${ }^{24}$. Also in this case a unique name - in terms of the historical period and geographical location - may indicate that this otherwise unknown Wincenty was not a Pole. Another question refers to the nationality of a Nieszawa burgher and royal servant ("seruitor noster"), i.e., Hannus Hagen. His case is known from the letter of King Władysław II Jagiełło to the Danzig City Council of 10 August 1428. He was received by the king and asked him to convince the Danzig local authorities so that they gave their permission to bring his wife, children, other family members and some unspecified goods and chattels to Nowa Nieszawa. In this very town, some debtors owed certain sums of money to Hagen and he wanted to recover the money from them ${ }^{25}$. Another resident of this town was an English merchant ("civis et mercator noster in Nyeschowa"), Thomas Kadon, and this can be inferred from the letter that King Władysław II Jagiełło sent to Grand Master Paul von Rusdorf on 26 May 1428. In this letter the king requested for a safe travel and passage for the letter's bearer along with his people, goods and chattels through the territory of the Teutonic Order's State (the purpose of this trip was not specified in the letter) ${ }^{26}$. A group of English merchants in Nieszawa (maybe being citizens of the town?) must have been bigger, since during the convention of estates held in Marienburg on 26 May 1428, the Grand Master gave into consideration the issue of the English who used

${ }^{23}$ GStAPK, OBA, No. 4766.

${ }^{24}$ GStAPK, OBA, No. 4913.

25 APG, Missiva, 300, 27/3, k. 17.

${ }^{26}$ GStAPK, OBA, No. 4943; J. Tęgowski, O powstaniu Nowej Nieszawy naprzeciwko Torunia (dokument lokacyjny miasta), Rocznik Toruński 16 (1983), p. 314-315. 
to live and work in this town and built warehouses ${ }^{27}$. This problem was to be discussed later after individual consultations and talks among city councillors. Perhaps it was another Englishman who was the protagonist of the letter sent by King Władysław II Jagiełło to Grand Master Paul von Rusdorf on 6 May 1426. The letter shows that a burgher from Nieszawa, Niclos Pherse, was received by the king and complained that when he was staying in Danzig, a local merchant Jakub Vynkemen along with a certain Hanusz Newdisch falsely accused him of stealing and contributed to his imprisonment. This fact exposed him to great distress and huge financial losses. He was released only when the real thief was captured. The Polish monarch addressed the Grand Master asking for safe conduct for Niclos Pherse to reside and move within the territory of the Teutonic Order's State so that - in Danzig - he could clear himself of charges and obtain compensation for the losses incurred ${ }^{28}$.

Foreign, or even exotic, visitors paid probably short visits to Nowa Nieszawa at that time. A letter drafted in Nieszawa on 23 December 1428 can shed some interesting light on this issue as in this letter Antoni "zupparius Cracoviensis" addressed Grand Master Paul von Rusdorf with a request for quite a big loan. This letter is very interesting, although still puzzling at times. The letter starts from Antoni informing that at the order of the Polish king Władysław II Jagiełło he received along "with his own” (members of his family?) salt mines on lease in Russia where he had just been sent by the monarch to look into the income and spending of this partnership and to take it over from his predecessor in this office. Meanwhile, the latter sent a batch of several thousand barrels of salt via the Vistula "ad locum istum" (probably to Kraków), of which Antoni, when he was there, was not informed, and especially of the fact that the previous salt miner was to bring and give him some money in cash at the order of Polish officials. The letter's author had certain doubts, however, whether his predecessor in the office could sell commodities in such a short time to gather adequate

27 „Item so hat unser herre homeister mit den staten handelung gehabtt, wie im vorkomen ist von etlichen Engelisschen, die wonunge und nyderloge czu Dybaw czu machen etc." - Acten, Bd. I, No. 384.

${ }^{28}$ GStAPK, OBA, No. 4583. 
resources. Moreover, it would take too long if Antoni had to travel from Nowa Nieszawa to Kraków by himself to take the money from the previous salt miner. Therefore, he asked the Grand Master to lend him 400 or 500 Hungarian florins to purchase the aforementioned transport of salt (the question may be asked for what purpose). He committed himself to pay back the loan either in the Roman curia, or in Breslau (Wrocław), or in Marienburg, through the agency of Prussian merchants. Ending his letter, Antoni tried to present himself as a reliable and trustworthy person: in the past he offered loans to subjects and envoys of the Teutonic Order in Breslau and Kraków if they addressed him with such requests, and never refused help. Various former Teutonic envoys could confirm this to the Grand Master, especially the late "dominus marschalcus Walrat" who was a special friend of Antoni ${ }^{29}$. Most probably, the salt miner had in mind Walrabe von Hunsbach who performed the function of the Marshal of the Teutonic Order between October 1424 and November $1428^{30}$.

There is no doubt that it was Antoni of Florence, of the Ricci family, who drafted the letter. In the 1420s. he and his brother were the leaseholders of salt mines in Wieliczka and Bochnia on behalf of King Władysław II Jagiełło. Yet, in March 1428, by decision of the monarch and on charges of mismanagement Antoni was dismissed from his function ${ }^{31}$. Was it possible that after a relatively short time Antoni was back in the king's graces and was given the lease on salt mines in Russia in the autumn this year? Or maybe the story described in the letter of 23 December 1428 did not have much in common with reality, and the smart Florentinian in this cunning way tried to extort a considerable sum from the Teutonic Order? It is difficult to give a satisfactory answer to these questions, but the issue per se is very interesting.

${ }^{29}$ GStAPK, OBA, No. 5016.

30 B. Jähnig, Wykaz urzędów. Dostojnicy zakonu krzyżackiego w Prusach, [in:] Państwo zakonu krzyżackiego w Prusach. Podziaty administracyjne i kościelne w XIII-XVI wieku, ed. Z. H. Nowak, R. Czaja, Toruń 2000, p. 103.

31 Cf. T. Jurek, Przyczynek do życiorysu żupnika Antoniego z Florencji, Teki Krakowskie 5 (1997), p. 47-52. The author did not consider in his deliberations the letter of 23 December 1428 . 
Among citizens of Nieszawa there were also fugitives from the Teutonic Order' State. One of the most famous was Hans David; he came from Liebstadt (Miłakowo, $37 \mathrm{~km}$ northwest of Olsztyn) and his father was a merchant there. However, in the early $15^{\text {th }}$ century, the real estates and feudal rents of his father were seized due to debts incurred and later auctioned off by the monastic authorities. The son, incapable of dealing with the situation and accepting it, got involved into legal disputes with the Teutonic Knights, initially in Prussia and later on also abroad. This dispute lasted several years, and he demanded compensation from the Teutonic Order for unlawful - in his view - seizure of his family estate ${ }^{32}$. Until 1430 Hans David lived in Nowa Nieszawa and was a citizen of the town. The period spent in the town was also one of the stages in his struggles for the recovery of the money and property his parents had left him ${ }^{33}$. The notarial deed issued on 19 May 1430 included a statement that in the presence of the local court called Schöffengericht Hans David handed over for safekeeping to his entrusted representative, Maciej Forster (a citizen of Nowa Nieszawa), four evidential documents in the dispute with the Teutonic Order over inheritance. He did it because he was to be received by King of Poland Władysław II Jagiełło, and he probably intended to familiarise the monarch with the essence of the conflict. This notarial deed discussed was issued by a notary public, Paul Hecht of Thorn, in the "New Town of Nieszawa" in the house of Vogt Jakub Wolf ${ }^{34}$, in the presence of Wolf and three lay judges (assessors) gathered there, i.e., Mikołaj Mislike, Mikołaj Murator (the bricklayer) and Jan Vrienstad as well as five witnesses selected from among the burghers: Andrzej Grucza, Jakub Schwebe, Maciej Beme (a Czech), Closz Engel and Mikołaj Grzech ${ }^{35}$.

32 As to the so called David's case cf. R. Czaja, Miasta pruskie a zakon krzyżacki. Studia nad stosunkami między miastem a wtadzq terytorialna w późnym średniowieczu, Toruń 1999, p. 154-157. The source provides information about older literary sources.

33 Details on those events can be found in S. Jóźwiak, Nowa Nieszawa, p. 16, 19-23.

$34,(. .$.$) in nouo opido Neschow et in domo discreti viri Jacobi Volff schulteti ibi-$ dem".

35 Secret State Archives Prussian Cultural Heritage Foundation (Geheimes Staatsarchiv Preußischer Kulturbesitz), Berlin-Dahlem, XX. Hauptabteilung, Pergamenturkunden (further as GStAPK, Perg. Urk.), Schiebl. 91, No. 2. 
More than sixty years ago Irena Janosz-Biskupowa, having quite a limited knowledge of the sources, formulated a hypothesis of the Polish ethnic origin of the majority of burghers in Nowa Nieszawa ${ }^{36}$. However, this case is much more complicated. The ethnical structure of the local community had not been that much homogenous in the very first period of the town's existence (until 1431); at that time Nowa Nieszawa had a more cosmopolitan character ${ }^{37}$. Nevertheless, after 1436 in newly rebuilt Nieszawa the Polish community gradually started to dominate, yet there were always some foreigners living and working in the town. A much telling example here is one of the complaints filed by burghers of the New Town of Thorn and included in the letter of the Thorn commander dated 1 December 1444. It says that some citizens of Danzig were to send their children and servants to towns near the Polish border (Nowa Nieszawa was an obvious destination as it was mentioned several times in this letter). There, under the guise of learning the Polish language they were to settle down and obtain citizenship with an intention to enter into partnerships with the locals to trade in grain and other commodities, concurrently using the possibility to circumvent restrictions applicable in Prussia at that time $^{38}$. The prevalent Polish ethnic structure of the town in the final period of its existence is indicated in a fragment of a letter, dated 30 March 1457, of the local authorities to the Danzig city council. One sentence says that due to the absence of a writer who could write in German, the letter was drafted in Latin ${ }^{39}$.

Nowa Nieszawa gave asylum to fugitives from the Teutonic Order's Prassian State. Probably beginning from 1443 a knight, Henryk Skolim, was a citizen of the town who also had a house and some other facilities; he was a temporary immigrant from Prussia. His estates were confiscated, in very unclear circumstances, by Grand Master Konrad von Erlichshausen,

${ }^{36}$ I. Janosz-Biskupowa, O potożeniu i przeniesieniu Nieszawy, Zapiski Towarzystwa Naukowego w Toruniu 20 (1954), Vol. 1-4, p. 172.

${ }^{37}$ Cf. above.

38 Acten, Bd. II, No. 395, p. 632.

39 „Notarium enim theutunicum non habuimus, ideo vobis sicut dominis latinum scribimus" - APG, Letters and documents, 300, D/7, No. 33. With errors in interpretation in: I. Janosz-Biskupowa, O potożeniu, p. 172, footnote No. 28. 
in return for which Skolim declared a private war to the Teutonic Order authorities ${ }^{40}$. This town also attracted fugitives from lower social classes. In a letter dated 29 June 1450, a Teutonic Vogt of Leipe (Lipieniek) informed the Grand Master also about a peasant who fled to Nowa Nieszawa (maybe he had some prospects of staying in the town); the local burgrave did not want to denounce him ${ }^{41}$. In 1452, three inhabitants escaped to Nieszawa from Dübeln (Dubielno in the Culmerland that belonged to the Teutonic Order's State in Prussia) with all their goods and chattels as they did not want to pay their annual rent. They were admitted by the then starost, probably Bogusław of Oporowo and Służewo ${ }^{42}$, who despite the intervention of the Teutonic prosecutor from Papau (Papowo) did not denounce them, and even granted them the right to obtain citizenship of the town. All these issues were reported in the letter to the Grand Master drafted by a Teutonic official on 9 November $1452^{43}$. At least since April that year another fugitive from the Prussia stayed in Nieszawa: a tailor from the Old Town of Danzig, Hans Nelitczke. This fact is acknowledged in three letters of 27 April, 29 April and 17 May 1452 44 . Yet, the letter drafted on 9 May 1453 and sent by the treasurer of the Crown, castellan of Sieradz and starost of Inowrocław, Jan Hincza of Rogowo to Grand Master Ludwig von Erlichshausen, says that a burgher from New Town of Elbing, Bartłomiej Hoffman, was a citizen of Nieszawa ${ }^{45}$, He complained to the Polish official about the injustice that he suffered from his former fellow countrymen

${ }^{40}$ OBA, No. 9088. On the life of Henryk Skolim and his family members in the last years of his life cf. K. Górski, Sprawa Skolimów i pierwsza próba oporu zbrojnego przeciw Krzyżakom w Prusach $w$ latach 1443-1446, [in:] idem, Studia i szkice z dziejów państwa krzyżackiego, Olsztyn 1986, p. 169-192; S. Jóźwiak, Nowa Nieszawa, p. 47-48.

${ }^{41}$ GStAPK, OBA, No. 10299.

${ }^{42}$ Cf. Urzędnicy kujawscy i dobrzynscy XII-XV wieku. Spisy, edited by J. Bieniak and S. Szybkowski, ed. A. Gąsiorowski, Kórnik 2014, p. 220. M. Biskup suggested that the then starost of Inowrocław and Nieszawa was Jan Hincza of Rogowo (cf. M. Biskup, Zjednoczenie Pomorza Wschodniego z Polska w potowie XV wieku, Warszawa 1959, p. 112-113). However, no evidence cannot corroborate this hypothesis.

43 GStAPK, OBA, No. 11555.

${ }^{44}$ GStAPK, OBA, No. 11181, No. 11222, No. 28861.

45 „(...) Bartholomeus Hoffman quondam ciuis noue ciuitatis Elbyng (...) ciuis moderni Nyessoviensis". 
(and specifically, from burghers from the Old Town of Elbing) ${ }^{46}$. A similar case concerned a citizen of Nieszawa (and a former citizen of Dirschau) Janusz (Hannus) Flysser, and this fact is reflected in the letters dated 29 April 1452 and 9 May and 5 November $1453^{47}$. In 1459 some citizens of Culm were staying in Nieszawa as fugitives, together with the former local mayor Jan Matzke ${ }^{48}$.

One cannot ignore the fact that since the 1430s. a Jewish community, with its population number hard to estimate, probably lived in Nieszawa. They came from Poznań, and representatives of this community dealt with usury and minor trade ${ }^{49}$. At least since 1448 an eminent physician, "Master Meyen", resided in the town for some time. His advice was sought by such personae as Grand Master Konrad von Erlichshausen, a Teutonic knight based in the Osterode region, Jan Bażyński, and perhaps also the former king of Denmark, Norway and Sweden, Erik I of Pomerania ${ }^{50}$.

\section{The political role of the town}

As already mentioned, Nowa Nieszawa developed in the territory, whose political importance substantially increased after signing the Treaty of

${ }^{46}$ GStAPK, OBA, No. 12021

${ }^{47}$ GStAPK, OBA, No. 12021, No. 12487, No. 28861.

${ }^{48}$ Archiwum Państwowe w Toruniu, Kat. I - Listy i dokumenty, No. 1864, No. 1876; „Item czugedencken, das dy vom Colmen stets czu Dybaw sein” - Neues Material zu Toeppens Acten der Ständetage Preußens, hrsg. v. F. Prowe, Mitteilungen des Coppernicus-Vereins für Wissenschaft und Kunst zu Thorn 37 (1929), No. 9, p. 83.

49 S. Joźwiak, Kontakty komturów toruńskich z Żydami z Nowej Nieszawy w latach czterdziestych XV wieku, Rocznik Toruński 29 (2002), p. 42-44; idem, Nowa Nieszawa, p. $50-51$.

${ }^{50}$ M. Broda, Żydowscy lekarze w państwie zakonu krzyżackiego w Prusach w późnym średniowieczu, Kwartalnik Historii Żydów (2011), No. 4, p. 435-440; eadem, Lekarze w państwie zakonu krzyżackiego w Prusach w XIV-XV wieku, Kraków 2013, p. 121-125; M. Duda, Jewish Physicians in the Teutonic Order's Prussian State in the Late Middle Ages, [in:] Fear and Loathing in the North. Jews and Muslims in Medieval Scandinavia and the Baltic Region, ed. C. Heß, J. Adams, Berlin-Boston 2015, p. 130-135; S. Jóźwiak, Nowa Nieszawa, p. 50-51. 
Mełno (1422). Since then, the half of the Vistula river's course in this place became the boundary between the Kingdom of Poland and the Teutonic Order's State. It is not surprising that the conventions and meetings held by rulers and negotiators on both sides were frequently organised right here or in the direct neighbourhood. An example may be the talks - between 2 and 7 June 1424 on the Vistula bank near Nowa Nieszawa - in which took part Grand Master Paul von Rusdorf and King Władysław II Jagiełło ${ }^{51}$. The Polish monarch used to visit this place on several occasions almost every year (in 1424, 1425, 1426, 1428, 1429 and 1430) ${ }^{52}$.

In article 31 of the Treaty of Brześć (1435) a new provision was introduced, the aim of which was the settlement of border conflicts. It was to be the task of mixed courts of arbitration consisting of two Teutonic commanders appointed by the Polish king and two Polish provincial governors or other persons performing similar functions, or of a similar position, appointed by the Grand Master ${ }^{53}$. Although the practice of establishing these institutions started to deviate from the assumed theoretical objectives quite early on, yet until the end (i.e. until 1454), Nowa Nieszawa had remained one of the most important places for holding such events. For some of the years mentioned in sources, certain details can be found as to mutual disputes and attempts to solve them undertaken by both parties. A good example are the complaints collected by the subjects of the Teutonic Order that were to be submitted to the mixed court of arbitration sitting from 6 January 1442 in Nowa Nieszawa and Thorn. It is due to merchants from the latter city that a number of accusations against the Poles were formu-

${ }^{51}$ Extensively on those negotations cf. A. Szweda, Organizacja i technika dyplomacji polskiej w stosunkach z zakonem krzyżackim w Prusach w latach 1386-1454, Toruń 2009, p. 394-396.

52 GStAPK, OBA, No. 4292, No. 4423, No. 4431, No. 4583; GStAPK, Perg. Urk., Schiebl. 47, No. 15; CEV, No. 1220, No. 1222, No. 1350, No. 1356, No. 1415; Kodeks Dyplomatyczny Litwy, ed. E. Raczyński, Wrocław 1845, No. 4, p. 317-318; Die Staatsverträge des Deutschen Ordens in Preußen im 15. Jahrhundert, hrsg. v. E. Weise, Bd. I, Marburg 1939, No. 167; A. Gąsiorowski, Itinerarium króla Wtadystawa Jagietty 1386-1434, Warszawa 2015, wyd. 2 (Itineraria Jagiellonów, t. 2), p. 102, 104, 107, 111, 113, 116.

53 Cf. A. Szweda, Organizacja, p. 271 and further. 
lated ${ }^{54}$. For instance, the starost of Nieszawa was to collect rent from the islands on the Vistula river that belonged to the locals in Thorn; he did not allow them to fully benefit from those islands, brought his horses there to eat the grass, and ordered to cut down oaks and other trees growing there ${ }^{55}$. The burgrave of the Dybów castle ordered to drown, without any reason, a man, who had come from afar and wanted to obtain a citizen-

${ }^{54}$ Probably some of them were still a perceptible echo of events mentioned in earlier sources. In a letter of 4 October 1440 Queen Widow, Zofia of Poland, replying to the complaint of Grand Master Paul von Rusdorf about the conduct of the burgrave of Nieszawa (and of Dybów) towards the subjects of the Teutonic Order's State promised to persuade the burgrave to release - without any bail - the captured man (a merchant?) and to return his money, horses and other items - GStAPK, OBA, No. 7763. These complaints of the Grand Master were addressed by bishop of Cracow, Zbigniew Oleśnicki, in a long letter sent on 8 October 1440 from Kielce. He hugely regretted the injustices that subjects of the Teutonic Order were to suffer from the burgrave of Nieszawa. He assured that the intention of the king and the magnates was to keep peace. The letter of the Grand Master was sent to Kraków to the queen and barons who were debating there on the Hungarian issues. The bishop was also informed that they sent the letters to the burgrave of Nieszawa asking that both he and his people should refrain from inflicting any injustice or harm on subjects of the Teutonic Order, which would violate the peace terms. The bishop reminded also the Grand Master that the officials and the inhabitants of Poland file numerous complaints as to the unlawful behavior and conduct of some border commanders and their subjects. Finally, referring to the content of the letter of the Grand Master, Zbigniew Oleśnicki addressed the case of some subjects of the Teutonic Order who were captured by the burgrave of Nieszawa. In the absence of any knowledge of the events he was not capable to respond to this issue. Nevertheless, he mentioned that he wrote about this to barons of the Kingdom of Poland who were debating in Kraków, with a request to suggest the burgrave temporary release of the captured persons under the pledge of the bail paid (another solution is mentioned in the abovementioned letter of the queen to the Grand Master), and the problem of the legitimacy of their imprisonment and charges formulated against them would be resolved by judges on both sides of the dispute at the next meeting (at the border) of the mixed court of arbitration - GStAPK, OBA, No. 7764. Bishop of Włocławek, Władysław of Oporowo, made a very general mention of the above events in his letter to the Grand Master, drafted on 18 October 1440 in Oporowo. He expressed his regrets only because of the damage inflicted on the Teutonic subjects also by the residents of Nowa Nieszawa - GStAPK, OBA, No7768

55 Both parties committed to solve amicably this issue, of which we know from the letter of the Thorn commander to the Grand Master of 18 May 1442 - GStAPK, OBA, No. 8130 . 
ship of Thorn. This burgrave, together with residents of Nieszawa, used to stop and persecute people who were heading to Prussia, as well as he would open and take merchants' letters. Even pilgrims returning probably from the Holy Land ("vom heiligen grabe") were not exempt from restrictions (if they came from the Teutonic Order's State and other countries). The locals in Nieszawa forced them to go the Dybów castle, and those people were stripped naked and searched there. This situation was to happen to one burgher from Danzig on Christmas Eve (1441?). The burgrave also would not allow fishermen from Thorn to do their job and requisitioned all the items used for fishing. If they wanted to regain freedom, they had to buy themselves out for five pounds of pepper. In addition, a man was shot in the leg on a public road, and shots were fired from the castle in Dybów. Thorn residents also complained that the Poles refused to accept in Nieszawa, and send further into their territory, the letters of Prussian towns, of the Grand Master and the Teutonic Order officials (which was once agreed upon by both parties), while Thorn locals were obliged to take care of sending letters from Poland further into the territory of the Teutonic Order's State (and these activities generated certain costs). The dissatisfaction of the Teutonic subjects was also evoked by the fact that the Poles used to avoid the old trade land routes and chose to travel through Bydgoszcz and Nakło, which had an adverse financial effect on Thorn and the crossing on the Vistula ${ }^{56}$. An additional complaint, which was to be recognised at the same court meeting, was recorded in a cartulary from the chancery of the Grand Master. The commander in Thorn stressed that the Poles were cheating on charges while crossing the Vistula in Thorn. The idea was that a wagon, loaded with grain or other commodities, used to come from Cuiavia drawn by two horses. In Nieszawa one of those horses was unharnessed, and the other one was pulling it onto the crossing raft. In other cases, in heavy-loaded wagons the Poles reduced the number of

56 The State Archives in Toruń (Archiwum Państwowe w Toruniu), Kat. I - Listy i dokumenty, No. 1077; GStAPK, OBA, No. 7130; Secret State Archives Prussian Cultural Heritage Foundation (Geheimes Staatsarchiv Preußischer Kulturbesitz), Berlin-Dahlem, XX. Hauptabteilung, Ordensfolianten (further as GStAPK, OF), No. 15, p. 96-97. 
horses from four or three to two or one, which was obviously related to the amount to be paid for the crossing ${ }^{57}$.

The report of the commander in Thorn, Albrecht Kalb, of 30 September 1450 is also interesting for the contexts discussed as he extensively informed the Grand Master that due to procedural reasons the mixed court of arbitration, scheduled for the end of September this year in Nowa Nieszawa and Thorn, was not held. It was due to the fact that the commander from Swetz, earlier appointed judge by the king, died and his successor was not nominated. The Poles were represented by voivode of Brześć and starost of Inowrocław, Jan of Kretkowo (who, with the consent of the Teutonic Order, used to replace previously nominated yet seriously ill voivode of Sieradz - Jarand of Grabie and Brudzewo). The second of the Polish judges, the castellan from Sieradz, Wawrzyniec Zaremba of Kalinowa (in the aforementioned source he was not mentioned by name, and his personal data are known from other sources $)^{58}$, was not able to get there on time. In these circumstances, the court convention was not held, and the commander of Thorn - at the request of representatives of the local government in Thorn who were particularly concerned - sent a complaint to King Kazimierz Jagiellon about the attitude of the Poles, and a report to the Grand Master with a suggestion to undertake relevant measures ${ }^{59}$.

The complicated political situation in Poland in the late 1440s. sometimes impinged on the current state of relations between Poland and the Teutonic Order's State. In a letter drafted 17 December 1448 Thorn commander, Albrecht Kalb, informed Grand Master Konrad von Erlichshausen that the then voivode of Brześć and starost of Inowrocław, Jan of Kretkowo, was said to be in possession of reports (of unknown origin) that during that winter the burghers of Thorn would attack and burn Nowa Nieszawa. For this reason, he strengthened the castle in Dybowo, increased the number

57 GStAPK, OF, No. 15, p. 97-98.

58 GStAPK, OBA, No. 10352, No. 10387.

59 GStAPK, OBA, No. 10393. Information on circumstances of these events can be also found in earlier correspondence, also dated September this year, sent by the Poles to Grand Master Ludwig von Erlichshausen. These letters refer to the fears of senders that resulted from the plague of bubonic fever taking its toll in Torun at that time - cf. GStAPK, OBA, No. 10352, No. 10369, No. 10387. See also A. Szweda, Organizacja, p. 277-279. 
of the castle's crew members, brought cannons and took other preventive measures. He ordered his subjects to be ready to quickly appear under arms in case of emergency mobilisation. Being somewhat confused, the Teutonic official carried out a community inquiry in Thorn, but none of his informants knew anything about any intentions to raid Nieszawa. Therefore he expressed his hope that when the Thorn commander was to come (who was temporarily absent), he would meet the starost to explain all the misunderstandings ${ }^{60}$. It seems that this matter was resolved amicably and the terms of the Treaty of Brześć, in force at that time, were not violated by any of the parties involved.

The radical change of the political situation along with the outbreak of the uprising of the local community ruled by the Teutonic Order against the Order's authorities (in 1454) and, as a consequence, the Thirteen Years' War between the Kingdom of Poland and the Teutonic Order resulted in doubts as to the further existence of Nowa Nieszawa. Its destruction was consistently demanded by residents of Thorn who, since 1454 , became the subjects of King Kazimierz Jagiellon. The monarch himself was playing for time in this case, yet growing financial problems caused by the war forced him eventually to take the final decision. Pursuant to two documents issued in 1460, he ordered to demolish the town and move it 4 miles up the river. In autumn 1462, the destruction of Nowa Nieszawa opposite Thorn was already an accomplished fact (although the buildings in existence were not completely demolished). Only the castle in Dybów remained in its original place ${ }^{61}$.

Nowa Nieszawa, chartered on the Vistula river on the Polish and Teutonic border after 1423 , seems to have been a rapidly growing town in economic and political terms. Owing to its location along an extremely important trade route as well as in the direct vicinity of the Teutonic Order's State, Nowa Nieszawa attracted enterprising individuals (mostly merchants and craftsmen) of various ethnic backgrounds, i.e., residents of the Kingdom of Poland, the English, Germans, Czechs, Dutch and Jews. On

${ }^{60}$ GStAPK, OBA, No. 9751.

${ }^{61}$ Extensively on the destruction of Nowa Nieszawa, cf. S. Jóźwiak, Nowa Nieszawa, p. 51-54. 
the other hand, the town's border location and conditions conducive to development resulted in the presence of fugitives from the nearby State of the Teutonic Order who were often in conflict with the state authorities or former fellow countrymen. The functioning of Nowa Nieszawa is all the more worthy of attention as the position and importance of this town was formed in quite a constrained timeframe: the time span between granting the town with the charter and razing it to the ground took a little less than four decades, and the town's development was further halted by brutal invasions of the Teutonic and Thorn-based troops in 1431 and resultant destructions. It should be noted, however, that Nieszawa owes its phenomenon primarily to an extremely favourable location on the border between the two countries. 